\title{
To Reward and Punish: A Classification of Union Political Strategies
}

\author{
TAYLOR E. DARK III \\ Doshisha University, Kyoto 602-8580, Japan
}

The complexity of union involvement in American politics has frequently been underestimated in the existing academic literature. For this reason, it is helpful to develop a comprehensive classification of the bargaining strategies adopted by unions as they interact with elected officeholders. This classification allows a more systematic analysis of the preconditions and associated advantages and disadvantages of various union strategies in both party nominating processes and general elections. It also shows that the decision to enter electoral politics is best seen as the beginning of a complex, ongoing, and multidimensional process rather than as the end-point of a "single-play" game. Lastly, the classification demonstrates that a wider range of political choice is available to organized labor than is commonly recognized, notwithstanding the real and continuing constraints on labor power.

\section{Introduction}

How do labor unions in the U.S. bargain with the country's elected officeholders? The question is of obvious importance, yet frequently it has been eclipsed by debates over what strategy labor should pursue and, in particular, the tired and unproductive question of whether unions should establish their own, separate political party. While many have thus opposed labor's incorporation into the two-party system, considerably fewer have sought to systematically describe or analyze it. My goal, therefore, is to classify the bargaining techniques that labor unions (and, by implication, other interest groups) actually use to interact with elected officeholders (mainly, but not exclusively, from the Democratic party). A review of these strategies will show that unions continue to possess a wide range of bargaining options long after they have forsworn the formation of their own political party. Moreover, a proper understanding of these diverse choices helps us redirect analytical attention to how the labor/Democrat alliance evolves over time and to the role of skill and strategy in the decision-making of both unions and politicians.

Many accounts of the political strategies of unions argue that the endorsement of Democratic candidates actually reduces union bargaining power, leading unions into a dependent position from which they can only beg for support or make empty threats of defection. "As dependent pressure groups, they select from'among candidates over whom they have no control," asserts labor journalist Kim Moody. "Within the con- 
fines of the Democratic party there is no way out of this dilemma, and no way to reverse the decline of labor's political influence that has been under way since the early 1970s" (Moody, 1988, p. 163). From a more scholarly perspective, Bok and Dunlop also conclude: "Labor's power to demand special concessions from a Democratic administration is often blunted because the Federation has little choice but to support the party." Bok and Dunlop (1970, p. 423) acknowledge that labor leaders may counteract this danger by threatening "to cut back their campaign efforts or to endorse more Republican candidates," but "unless the Republicans are prepared to make real concessions in exchange for labor support, these veiled threats may not seem credible enough to induce a marked change in Democratic policies" (Bok and Dunlop, 1970, p. 400). While some authors, such as J. David Greenstone (1977) in his classic, Labor in American Politics, or, more recently, Gilbert Gall (1988) in The Politics of Right-to-Work, have emphasized the ways in which unions can alter political outcomes through effective bargaining within the existing party system, it is has not been uncommon, especially since the rise of left-wing labor historiography in the 1960s, for labor's bargaining power to be described as inherently and irretrievably weakened - even eviscerated - by the absence of a political party formally aligned with labor (see, for example, Aronowitz, 1998; Davis, 1986; Green, 1980).

Such arguments imply that the capacity of organized labor to engage in effective political bargaining dissipates once it eschews the formation of its own party. The trouble with this view, however, is that it conceptualizes labor's decision to endorse Democrats as the final culmination of a single-play game, after which all subsequent choices are sharply confined and of marginal significance. This kind of argument strips the existing bargaining relationships between labor unions and the Democrats of all complexity and provides no tools for understanding the day-to-day interactions that actually characterize American politics.

A better choice is to think of the labor/Democrat alliance as a complex, ongoing, and multidimensional game that allows many opportunities for the deployment of both negative and positive inducements. Although under normal circumstances labor cannot launch its own party, there are many intermediary steps, involving subtle gradations of support or opposition, that provide unions with an effective set of threats. This is especially so because unions in the U.S. typically bargain with individual candidates within a party, not with the party as a single entity or organization. In effect, organized labor's role in the party system is constantly renegotiated each time a candidate seeks help, and each time labor decides whether or not to provide it.

Labor's overall strategy since the days of Gompers has, of course, been to work within the two-party system to advance union interests by cutting deals with individual politicians. But the techniques for cutting these deals have varied widely. My classification divides labor's strategies into two groups: those that are pursued in general elections, where competition typically occurs between Democrats and Republicans, and those pursued within Democratic party nominating processes, where Democratic candidates compete with each other (Table 1). For analytical purposes, I further sub- 


\section{Table 1}

\section{Union Bargaining Options in American Politics}

\section{STRATEGY}

MAIN ADVANTAGES

MAIN DISADVANTAGES

In General Elections (descending from punishment to reward)

1. Defection to a non-Democrat or neutrality

\section{An "empty" or a delayed endorsement of a Democrat}

3. "Full" endorsement of Democrat
Severe punishment provides a strong demonstration effect; encourages competition by both parties for labor support

Sends a warning signal without "burning bridges"; shows labor independence; establishes future credibility

Allows access if Democrats wins; creates opening for good policy; helps in coalition-building; builds voter and elite loyalty
Few non-Democrats worth supporting; disrupts alliances with other Democrats; may cause labor disunity; requires narrowing of union agenda; conflicts with union member and leader voting loyalties

May lead to victory by conservative Republican; labor may have less access if Democrat wins; if Democrat loses, labor may be blamed; may hinder member mobilization

Democrats may take labor support for granted; labor is forced to downplay its own issues on behalf of party strategy; closeness and loyalty make adversarial bargaining more difficult later

Within Democratic Party Nominating Processes (descending from punishment to reward)

4. Endorse an intraparty challenger

5. Neutrality, an "empty" endorsement,or a delayed endorsement

\section{Join a bandwagon}

7. Endorse early or at a critical juncture
If successful, major debts are earned and labor secures reputation as kingmaker; if Democrats win, access and good policy should follow

Sends a strong warning signal to candidates without "burning bridges"; illustrates labor independence

Decision making is easy: labor supports a clear winner; no danger to labor reputation

If successful, major debts are earned and labor secures reputation as kingmaker; if Democrats win, access and good policy should follow
If unsuccessful, incumbent owes labor less and may exclude it from policy making; failure hurts labor's reputation; may cause labor disunity or conflict with allied interest groups

May disrupt ties with friendly politicians; labor may be isolated from all candidates; labor creates does not build loyalty or enhance reputation as kingmaker

Labor earns little gratitude and does not develop its reputation

If unsuccessful, winner may exclude labor; failure hurts labor's reputation; unity on early choice is difficult; may cause labor disunity or conflict with allied interest groups 
divide each group to obtain a list of three kinds of strategies that are typically used in general elections, and four kinds that are used in nominating processes. Although many of these strategies shade into one another in real-life circumstances, herein each one is given a separate discussion that identifies its preconditions and characteristic advantages and disadvantages. While there can be no substitute for the detailed analysis of particular conjunctures, this classification provides a comprehensive template that can be applied when evaluating any episode of union intervention in American electoral politics. In addition, the classification can help guide further research by predicting various causal relationships and outcomes which can be tested empirically.

\section{General Election Strategies}

Maneuvering in general elections presents major difficulties for unions, and as a result, it is often argued that labor has no choice but to simply settle for the tactic of endorsing whomever the Democrats happen to run as a candidate. But this generalization elides several issues. First, it is far from the case that Republicans and other nonDemocrats are always unavailable or undesirable as possible alternatives to the usual endorsement of a Democrat. Second, there may be ways for labor to register its displeasure with the Democratic candidate that fall well short of a full endorsement of the opposition. If this is so, Democratic responses to these intermediate strategies may grant labor continuing room to maneuver even during a general election competition between Democrat and Republican. Much depends on the characteristics of the actual situation, such as the nature and positions of the candidates, the closeness of the race, the likely outcomes in other contests (such as related legislative or executive races), the size and value of union resources, the role of other interest groups, and so on.

Strategy 1: Defection to a Non-Democrat or Neutrality. Defection to a non-Democrat is usually considered a non-option for American unions because, as we are so often told, "they have nowhere else to go." But on the face of it, this is clearly wrong: virtually all American unions have, at one time or another (and not just in the distant past), endorsed Republicans in one race or another; on occasion, they have also endorsed third-party or independent candidates. Union endorsements of Republicans are actually a common feature of every election season, although most endorsements do go to Democrats. In 1998, for example, the AFL-CIO endorsed 27 Republicans running for the House of Representatives, hoping in this manner to secure some Republican support in a body where Democrats were now the minority (Greenhouse, 1998; Rosenthal, 2000). Labor political strategists claimed that 23 of the House Republicans had voted with labor more than 50 percent of the time in 1997 and now deserved to be rewarded with support for their reelection campaigns. Indeed, in 1998 unions gave at least $\$ 4$ million to Republican candidates at the federal level (and around $\$ 40$ million to Democrats) (Dark, 2000). At the presidential level, there have always been unions that are willing to endorse Republicans, most notably the International Brotherhood of Teamsters and some building trades unions in the 1970s and 1980s. In state and local elections - an area of union political involvement that remains understudied by schol- 
ars - labor endorsements of Republicans are rather common, as seen most clearly in the frequent support of building trades unions (but not just them) for Republican mayoral candidates (such as Los Angeles's Richard Riordan and New York's Rudolph Giuliani). Too often, it seems, our image of the choices that unions face in politics is drawn only from presidential elections, where the notion that Republicans are completely unavailable as bargaining partners has had more support.

The fact that some unions have endorsed Republicans and provided them with valuable campaign support has several consequences. First, it surely encourages competition in selected races between Republican and Democratic candidates over areas of public policy that matter to unions. As a result, at least some unions can secure benefits that they might not otherwise obtain (although frequently at the cost of a marked constriction of the union agenda to those issues - usually narrowly materialistic and parochial - on which even Republicans are prepared to compromise). Second, when defections to non-Democrats occur, Democratic politicians across the board pay attention: Displays of union defection create a "demonstration effect" that may have ramifications over space and time far beyond the particular race in question. The fact that the Teamsters, for example, has endorsed GOP candidates in the past no doubt makes its threat - and that of other unions - to do so in the future all the more credible.

But the strategy has obvious limitations. First, it depends on the assumption that Republicans (or other non-Democrats) need labor support - that they find such'support valuable to meet their electoral (and, perhaps, legislative) ambitions. But politicians who are well-funded and supported from other sources and ahead in the polls may see no reason to bargain. Second, the strategy assumes that Republicans will be able to make concessions to labor in return for support. But many Republicans face pressures from internal party constituencies not to do so, and their position within the party would be jeopardized if they became too friendly to labor. Third, most unions have a wide range of issues that are of concern to them, and Republicans are frequently unwilling to compromise except on one or two issues that are narrowly framed. Thus, this option appeals most to unions that have put narrow or particularistic demands at the center of their political program. Fourth, defection from one Democratic candidate's coalition tends to disrupt alliances with other Democratic officeholders, even if that is not intended, and also places great tensions on alliances with other progressive interest groups. These elite bonds of loyalty can be valuable, and unions resist weakening them. Fifth, both union members and leaders may have become habituated to voting for Democrats, making it harder to convince them to switch to a Republican or other non-Democrat for short-term strategic reasons.

Despite these obstacles, union endorsements of Republicans do continue to occur, especially in races (such as many congressional and state legislative seats) where the Democrats stand no chance of winning anyway. As a result of these endorsements, some Republican members of Congress can be counted on to support labor's interests, and there are many more Republicans in state houses and mayor's offices with similar inclinations. For example, in early 2001, 32 House Republicans (many of whom 
had been endorsed by the AFL-CIO) wrote a letter to President George W. Bush publicly criticizing the decision by his administration to effectively prohibit "project labor agreements" favoring the use of unionized labor on federally financed building projects (Greenhouse, 2001). These Republicans were mainly from the Northeast and Midwest and frequently had close ties to the building trades unions that stood to lose the most from the administration's decision. While this support was only on a very narrow issue, it showed that labor could extract some benefits even from Republicans. While this was no threat to the labor/Democrat alliance overall, it seems likely that Democrats running against these congressional Republicans would face strong pressures to be extremely pro-labor if they were to have any chance at securing union endorsements against these "labor-friendly" Republicans.

Much less drastic than defection, but similar in its costs and benefits, is neutrality. Like defection, neutrality is most likely in races where the costs of a Democratic defeat are low or where the Democrats stand no chance of victory. Perhaps the most prominent use of this strategy in recent decades was in the 1972 presidential election, when the AFL-CIO chose to remain formally neutral in the race between Democrat George McGovern and Republican Richard Nixon (Wilson, 1977, pp. 43-45). This decision grew out of the strong dissatisfaction on the part of AFL-CIO President George Meany with McGovern's liberal positions on foreign policy and his close ties with new social movements that threatened labor's traditional role in the Democratic party. The goal in adopting neutrality was to teach the Democrats a lesson: Labor did not always have to endorse even the presidential nominee if that nominee and other party players did not meet with labor's approval. The fact that McGovern seemed headed for defeat anyway made it seem like a good opportunity to pursue such a strategy, and neutrality in the presidential race did not stop the federation from working to elect Democrats to other offices. Moreover, the federation-level decision did not stop many of the national unions from separately making endorsements of McGovern. In this case, then, one section of the labor movement was able to punish McGovern, while other parts were able to provide his campaign (and that of other Democrats) with much-needed support. Arguably, labor could hope in this manner to create a demonstration effect for future Democratic candidates, while at the same time softening the actual impact on 1972 electoral outcomes. Indeed, in the aftermath of this episode, as Wilson (1977, p. 45) notes, party leaders did engage in a partial renunciation of "McGovernism" and did try to mend fences with union leaders. And there can be little doubt that when Jimmy Carter chose to seek an AFL-CIO endorsement in 1976, the fate of the previous Democratic nominee was not forgotten.

Despite its occasional utility, neutrality is a difficult strategy to implement when unions have a wide agenda and deep ties across the board to Democrats. Neutrality inevitability disrupts partisan alliances, threatens interest-group friendships, stimulates internal conflict between liberal and conservative unions, and conflicts with longstanding loyalties among leaders and followers. Neutrality is also basically a negative and unexciting position - one which makes it all the more difficult to mobilize the membership for electoral activity. For all these reasons, neutrality, like defection, is 
rare in general elections. Still, the possibility that these drastic strategies could be used is part of the background condition for all bargaining between labor unions and Democratic candidates.

Strategy 2: An "Empty” Endorsement or a Delayed Endorsement. More attractive than defection or neutrality are strategies that allow labor to punish a Democratic candidate without imposing much damage on that candidate's chance to win in the general election. One such strategy is to formally endorse a Democratic candidate, but then refuse to follow up with a full commitment of union resources. This "empty" endorsement sends a message of dissatisfaction while still remaining within the confines of an alliance with the Democratic party. This strategy was used by several unions in the 1994 congressional elections, when large parts of the labor movement were angry at those Democrats who had voted in favor of the North American Free Trade Agreement. These unions could have recruited challengers to run against incumbents in Democratic primaries (see Strategy 4 ), but judged this to be a time-consuming and difficult tactic. Instead, they chose to endorse the candidate, but then seriously reduce or eliminate the sums donated to his or her campaign (Engel and Jackson, 1998). This punishment could be implemented without ruining the electoral prospects of Democratic candidates, yet it did have a sting that could concentrate the minds of members of Congress. Indeed, the union's ability to block the renewal of fast-track trade negotiating authority in 1997 and 1998 may have reflected a new and deeper appreciation among Democratic members of just these consequences for opposing labor on such an important issue (Shoch, 2000).

Another low-cost way of both registering dissatisfaction and eliciting interest from politicians is to delay an endorsement. This approach was used in the 2000 presidential election when several unions waited until late in the election season to make a formal endorsement. Notwithstanding the early federation-level endorsement of A1 Gore in October 1999, the United Auto Workers (UAW) and United Mine Workers (UMW) chose not to make any endorsement in the Democratic primaries, and both waited until late summer before making an endorsement in the general election. While these unions expressed interest in the independent presidential bid of consumer advocate Ralph Nader, few doubted that they would eventually end up endorsing Gore's candidacy or, at most, lapsing into neutrality. Still, their lateness in coming to a decision was a modest way of punishing Gore that may have encouraged the candidate to give greater consideration to their policy views. Indeed, the Mine Workers claimed that they had received assurances from the Vice President, "both verbally and in writing," that his environmentalism would not lead him to abandon the role of coal in the "nation's energy mix" (United Mine Workers, 2000).

With rather more credibility, the Teamsters also toyed with endorsing Nader, as well as Republican presidential candidate George W. Bush. In response, the Republicans made repeated efforts to cultivate the support of the union and its president, James Hoffa - even holding a special reception for the union leader at the Republican National Convention. Meanwhile, Al Gore redoubled his efforts to secure a Teamster endorsement, which was widely seen as crucial if the Democrats were to succeed in 
winning such swing states as Michigan and Pennsylvania. Courted by both sides, the Teamsters endorsed Gore in early September, and Gore arrived personally at the Teamsters convention to accept their support and plan coordination for the fall campaign. What did the Teamsters gain from this display of electoral independence? The New York Times reported that the Clinton administration, in an effort to assuage the union, "directed projects through federal agencies that would use Teamsters" (Berke, 2000). But publicly, at least, the Gore campaign offered no special concessions to the union, other than its overall commitment to defending both worker and union interests. What we cannot know is the extent - if any - to which the Teamsters extracted special promises behind closed doors in Hoffa's various meetings with Gore and President Clinton. What seems most likely is that both sides knew that an endorsement - and the important support that followed - would guarantee the Teamsters access to Democratic policymakers in a new administration and ensure a favorable hearing for the union's special requests.

The ultimate purpose of these maneuvers is to teach a lesson to candidates that they can and will be held responsible for their actions - that labor does indeed have a place to go: It can "go" to an empty endorsement or a delayed endorsement (or, if worse comes to worse, to neutrality or defection). The downside, of course, is that these actions may lead to an increased likelihood that a conservative Republican opposed to labor's interests will be elected and that labor will get the blame for the outcome. And if the Democrat does win, he or she may harbor resentment toward labor for its show of "disloyalty." These risks have prevented such techniques from being used regularly, and tend to reduce their credibility as threats. On the other hand, in some cases Republican candidates may actually be moderate in their attitudes toward unions and their issues, in which case unions can pursue their strategies in the confidence that should their schemes backfire - producing a Republican victory - the cost will not be so high. Also, in legislative races, the loss of a single seat to a Republican may not alter the partisan balance in the assembly as a whole, again reinforcing the ability of unions to engage in the punishments described here. Last, even if there are significant short-term costs accruing from a Republican victory, the punishment of a Democrat may provide considerable long-run benefit by enhancing the credibility of future threats.

Strategy 3: Full Endorsement of a Democrat. The third option in general elections is to simply endorse the Democratic candidate enthusiastically and go all-out in a display of loyalty and commitment to one's political friends. This is labor's strategy most of the time, and its pluses and minuses are well-known. The main benefit is that, once elected, Democratic officeholders will grant labor political access, protect it from Republican attacks, push many (but certainly not all) issues on labor's legislative agenda, and make union-supported appointments to those government institutions that implement union-related policy. The obvious disadvantage is that when this strategy is used alone, with no hint of either general election alternatives or intra-party maneuvering, Democratic officeholders may grow quite smug in assuming labor's support. Moreover, as the unions grow ever closer to the candidate's and the party's campaign effort, their capacity to engage in tough, adversarial bargaining is diminished. Also, 
as the unions become entwined in the party's own calculations, they will face strong pressures to couch their issues in ways more favorable to the party than to the interests of union members (Greenstone, 1977).

Certainly, if labor is totally locked in advance into supporting every Democratic nominee to the maximum extent possible, all bargaining power is lost, and Democratic nominees have little rational interest in giving labor demands special consideration over those pressures that may come from constituencies that are still "in play." In reality, though, Democratic politicians always have to consider the possibility that excessive smugness on their part will stimulate the general election tactics mentioned above or the intra-party options detailed below. Ultimately, labor and the Democrats make deals on an election-by-election and candidate-by-candidate basis, notwithstanding the ongoing and mutual commitment to trying to work together most of the time. Despite the trust that is built up through many iterations of election-year endorsement decisions, neither side can count on the total loyalty of the other. Thus, if handled properly, the standard labor endorsements of Democrats do not require unions to abandon their independence or their distinctive issue agenda.

\section{Nominating Process Strategies}

Strategies involving nominating politics are relevant for any position - from state legislator to member of Congress, or from governor to president - where there is an official procedure to determine who carries the party label. Theoretically, labor could intervene in both Democratic and Republican nominating processes, but for numerous reasons the most common strategy has been involvement in Democratic party nominations. Whether these nominations are determined through a primary election open to all party voters or a convention only for party activists makes little fundamental difference: The basic strategic options will be the same, even if the tactics vary in response to institutional form. These intra-party maneuvers afford labor much greater flexibility and are much easier to pursue than are general election interventions. Their great virtue is that they allow errant officeholders to be punished while still working within the framework of the Democrat/labor alliance, thus avoiding the high risks involved in general election brinkmanship.

Strategy 4: Endorse an Intra-Party Challenger or Neutrality. A strategy that is unique and potent in its ability to inflict punishment on an incumbent officeholder is to endorse an intra-party challenger when the incumbent seeks renomination. Unions can choose to support a challenger who has emerged on his or her own, or they can recruit their own candidate (including, possibly, a union member). In either case, unions can deploy all of their usual campaign tactics on behalf of the challenging candidate. If labor succeeds in nominating its own choice, the incumbent will have been decisively punished (a useful demonstration effect to other politicians), and there will be a new nominee more friendly to labor and highly indebted to it for his or her success. If labor fails, however, the costs may be high, as the incumbent (and other politicians) will have learned that labor's capacity to punish is actually rather limited and that a 
refusal to follow its lead may have few consequences. Failure also undermines labor's reputation more broadly, revealing it as a force that is not capable of delivering outcomes within the party.

Clearly, this is a very risky strategy; nonetheless, it has been used on occasion in presidential politics and other races. A notable instance at the presidential level occurred in 1980, when discontented unions joined together to promote Senator Edward M. Kennedy's bid to replace Jimmy Carter as the Democratic presidential nominee (Dark, 2001, pp. 121-23). Several union leaders initially encouraged Kennedy to enter the race, and others joined the campaign once he declared his candidacy. The labor movement ended up split down the middle, with the federation neutral and two roughly equalsized sets of unions allying behind Kennedy or Carter. As the Kennedy insurgency unfolded, the administration took urgent steps to head it off by trying to pressure undecided unions to stay in the president's coalition. These "swing" unions were not shy about demanding concessions: the Steelworkers and textiles unions sought and received forms of trade protection; maritime unions secured administration support for "cargo preference" legislation; the building trades got new administration commitments to protecting the Davis-Bacon Act; and the Autoworkers received administration support for the Chrysler loan guarantee (Drew, 1981, p. 224). These and other perquisites were used to lure the unions back into the Carter camp, and the unions gladly accepted them as their expected due for staying loyal to a president in deep trouble.

The 1980 intervention thus demonstrated that sponsoring an intra-party challenger could force an incumbent to take labor's demands - or at least some of them - more seriously. Unfortunately, the Kennedy challenge was also probably one factor (among many) that led to Carter's defeat by Ronald Reagan in the general election. Alas, this is always the problem with sponsoring a challenger, and it is especially an issue in presidential elections where the general election results are frequently competitive and uncertain. Therefore, this strategy works best in races where Democrats are virtually certain to win in the general election, i.e., a "safe" legislative seat or executive office. In this case, there is not much danger that the intra-party challenger will produce a weakened nominee who is then defeated by a conservative Republican.

A good example of the latter kind of intervention was the union-backed effort in 2000 to remove Rep. Matthew Martinez as the Democratic nominee in California's 31 st congressional district. Martinez was a lackluster congressman who had voted "wrong" on "fast-track" trade authorization and other issues (Meyerson, 2000). Both national and local union activists were fed up with him and jumped at the opportunity to support the campaign of liberal State Senator Hilda Solis to replace him as the Democratic nominee. Working with other progressive activist groups, labor defeated Martinez in the June 2000 Democratic primary and secured Solis's nomination. Since the district was solidly Democrat, Solis sailed to an easy victory in November. From labor's point of view, this was a perfect intervention: a dubious Democrat had been replaced with a solidly pro-labor progressive, with virtually no downside. Meanwhile, Martinez's colleagues in Congress were put on notice that labor just might be able to prevent their renomination if they too strayed too far from labor's agenda. 
The ideal conditions for sponsoring an intra-party challenger will frequently not be present. Sometimes, an incumbent will be so popular and entrenched that he or she can defy interest groups with impunity, knowing full well that voters will remain loyal. In other cases, incumbents will know that labor will not dare to support a challenger when the result may just be a weakened nominee who is taken out by a Republican in the general election. Labor may also decide to sponsor a challenger, only to find that its electoral clout is insufficient, its interest group allies unenthusiastic, and its membership seriously divided. Despite these problems, the point still holds: Democratic incumbents seeking renomination are potentially vulnerable to labor defection from their coalition.

Strategy 5: Neutrality, an "Empty" Endorsement, or a Delayed Endorsement. As in general elections, in nominating contests labor can adopt a position of neutrality, make an "empty". endorsement, or simply delay its endorsement. Especially when an incumbent seeking renomination faces a major challenge, any one of these strategies can potentially be effective. In addition, the implied threat to pursue any of these options is usually credible, since the displacement of an incumbent by an intra-party challenger is not necessarily damaging to the party's chances in the general election. Indeed, this was precisely what President Carter and his aides knew in 1980, and it is why they made such strenuous effort to prevent union defections (or even union neutrality) in that year's nominating campaign. In a close nominating contest, just the threat of union neutrality may be sufficient to alter an incumbent's behavior. On the other hand, if there is no threat to renomination, not one of these strategies is likely to have much impact.

In the 2000 presidential nominating contest, several unions found neutrality desirable. By late 1999, Vice President Gore was facing a stiff challenge from Senator Bill Bradley, and for a while it seemed that Gore just might be defeated in the party's early primaries. He needed all the help he could get, and eventually he obtained the strong support of the AFL-CIO (see Strategy 7 below). As noted earlier, however, several unions were quite disappointed with Gore for his support of the Clinton administration's policy of trade liberalization. The UAW, Teamsters, and UMW had all had enough of the administration's policies and did not hear what they wanted from Gore. Despite the federation-level endorsement, they remained neutral through the entire nominating process. Ultimately, the threat from Bradley faded, partially due to the AFL-CIO endorsement, but had it not, the final actions of the neutral unions might well have become of much greater importance. As it was, their neutrality sent an early message to the Gore campaign that these unions were serious in their discontent and needed to have their concerns addressed.

While examples of neutrality are easy to find in nominating processes, "empty" endorsements seem rare. The reason apparently is that unions are not under as much pressure from Democratic allies to make endorsements in nominating processes as they are in general elections. Politicians have long recognized that it is difficult for unions (and other interest groups) to choose among friends in intra-party contests, and this recognition has made it easier for unions to opt out altogether when that seems attractive. Thus, the need to go through the charade of an empty endorsement is felt much 
less intensely in the nominating process than in general elections where neutrality may well be seen as tantamount to betrayal.

The other alternative for unions is to delay an endorsement, thus making a candidate wait longer and opening up opportunities for rivals to emerge. If the nominating contest becomes more competitive over time, there may come a moment when the degree of competition for union resources reaches a highpoint. Theoretically, unions could maximize their bargaining power if they could hold out until this ideal moment to make a decision. Indeed, this was one of the arguments put forth by disaffected unions in October 1999 when the AFL-CIO was debating whether to approve an early endorsement of Al Gore. Labor might get a better deal, dissenting unionists maintained, if it waited until a pressure point later in the primary season to make a decision, perhaps after Bill Bradley had won a few primaries and tightened up the race. While this option was rejected in 2000 (for good reason, it turned out), something close to it has been used in previous presidential nominating contests. In 1988 and 1992, for example, the lack of a clear front-runner and the presence of several good "friends" of labor in the race meant that the AFL-CIO was unable to agree on a collective endorsement. Instead, the national unions went their separate ways, in some cases making early endorsements, while in other cases trying to hold out until a crucial moment later in the process.

In contrast to general elections, however, a delayed endorsement in nominating politics is rather difficult to pull off effectively. The reason is that it is quite easy for a union that delays its endorsement to find that the race is decided very quickly, well before it has had time to intervene. The current presidential nominating process, with its emphasis on early fundraising and the "front loading" of primaries, increases the likelihood that the race will be decided early, thus making the strategy of delaying an endorsement quite difficult to implement. However, in nominating processes that are more simple - such as a single primary in a congressional district or state office an endorsement delay is much easier to orchestrate and may work more effectively.

Strategy 6: Join a Bandwagon. When a candidate is the clear front-runner and is unlikely to face any serious opposition in the nominating process, labor can endorse the likely winner, thus joining a bandwagon well on its way. Such support is, however, worth little to the candidate, since his or her victory seems likely in any event. Labor's support may therefore be appreciated, and remembered with a certain amount of gratitude, but it is not essential to the nominee's success. Unfortunately, this is precisely the situation that is characteristic of most incumbents in American legislative bodies, where primary challenges are generally rare and interest groups, including labor, find the prospect of sponsoring a challenger rather daunting. Hence, a recurring problem for labor bargaining within Democratic nominating processes is that there may not be anywhere to go in these processes when the incumbent has kept the home fences very well-mended.

Bandwagon situations sometimes emerge in presidential politics, although this is less common than in legislative races. President Clinton's bid for renomination in 1996 
is a notable recent example. Having worked over the previous years to discourage any party challengers, and riding high in the polls, Clinton was the consensual choice of party voters and elites. Labor had its dissatisfactions, like many other liberal constituencies, but was unwilling to sponsor an intra-party challenge. Instead, it joined the happy bandwagon and set its eyes on the general election, with special attention to the congressional races. The most the unions could hope for was to demonstrate their loyalty as good foot soldiers in the Democratic campaign, which labor did with gusto. Still, labor had no special bargaining leverage in 1996, and in this sense the bandwagon scenario comes closest to the "dependent" scenario sketched out by Moody and others. But recall that even if bargaining options are foreclosed in the nominating process, there may still be some maneuvering room in the general election (as described in Strategies 1 and 2).

Strategy 7: Endorse Early or at a Critical Juncture. A more impressive reward for an aspiring nominee is an early labor endorsement, well before the campaign for the nomination is in full swing. One of the most well-known cases of this in recent decades is the AFL-CIO's endorsement of Vice President Walter Mondale for the Democratic nomination in 1984. The federation endorsement was approved in October 1983, months before the first caucușes and primaries. By endorsing this early, and pledging the full support of the entire labor apparatus, the federation hoped to do three things: (1) achieve the selection of a pro-labor nominee; (2) promote an early victory by the nominee so he would be well-positioned for the general election; and (3) earn the gratitude of the nominee by demonstrating strong loyalty early in the process when it was unclear who would be victorious. By playing a crucial role in delivering the nomination to Mondale, labor achieved goals (1) and (3), but failed to deliver the nomination as early as desired due to Senator Gary Hart's challenge. Despite this, labor judged its overall involvement as successful, even though Mondale lost to Reagan in the general election.

A similar approach was used in 2000 , when the federation also made an early (October 1999) endorsement in the nominating contest and pledged the full support of its campaign apparatus. In this case, however, labor's support was even more valuable because Vice President Gore was, by the fall of 1999, in an increasingly perilous situation. With Senator Bill Bradley advancing in his own quest for the nomination, gaining in both fundraising and the polls, Gore was confronting a surprisingly strong intra-party challenge. Accordingly, some unions wanted to pursue Strategy 4, endorsing Bradley as a way of punishing (and perhaps replacing) Gore because of his support for the detested free-trade policies. But the majority of unions, and especially AFL-CIO President John J. Sweeney, wanted to go the other direction and endorse Gore at his moment of maximum peril (Rosenthal, 2000). An endorsement of Gore at this crucial moment, union strategists reasoned, would create debts and solidify loyalties that would stand labor well during a future Gore administration. The federation thus pursued this strategy, endorsing Gore and working avidly on his behalf in the crucial Iowa caucuses and New Hampshire primaries. By helping Gore defeat Bradley in these early contests, the AFL-CIO demonstrated its strength as a party player and 
achieved the selection of a nominee who, while hardly correct on all issues, was very close to organized labor on most issues and committed to granting unions privileged access.

One suspects that the Gore endorsement is the kind of intervention desired by the federation in every political contest. Coming in at the crucial moment to serve as kingmaker is an ideal role for an interest group to play. It certainly captures the attention of all those in the party who might aspire to seek the presidential nomination in the future, and encourages them to do what they can to stay in labor's good graces. In reality, though, it is frequently difficult to make an early endorsement because there are too many good candidates running for labor to make a choice. In this context, neutrality is often the only option available, not as a means for punishing an incumbent but simply as an expedient in a situation where any endorsement would involve a slap in the face to longstanding friends. Not coincidentally, therefore, in those cases where the labor movement as a whole has rallied around a candidate for the presidential nomination (Humphrey in 1968, Mondale in 1984, and Gore in 2000), the candidates were all current or former vice presidents who were already party frontrunners. Unfortunately for labor, this fact also means that the impact of labor's early intervention is limited by the common knowledge that many other party interests and factors could also be given credit for the front-runner's eventual success.

\section{Conclusion}

This classification of bargaining choices delineates how unions can operate to enhance their political influence even in the context of a party system that lacks a traditional "labor" or "left" party (by European standards). Several implications of the analysis follow. First, a well-developed sense of strategy is crucial for union leaders and operatives and can make a major difference in political outcomes. Arguably, many of the complaints made about the labor/Democrat relationship may reflect poor or unimaginative bargaining choices rather than an intrinsic quality of the relationship. There is, for example, nothing that stops unions from fielding their own candidates - perhaps union members themselves - in Democratic primaries, either in open races or to challenge and punish incumbents. The recent efforts by the AFL-CIO and many national unions to recruit and promote more union members as candidates illustrate the growing awareness that the labor/Democrat relationship allows wide room for tactical innovation and change over time.

Second, since choices and bargaining skills matter, so does the management of labor's reputation. Politicians frequently make decisions in a world of images rather than hard facts. One lesson for organized labor is that it must be shrewd about image management and carefully build its reputation as a force capable both of severe punishment and rich reward. Similarly, decisions about bargaining with Democratic officeholders have to be made with an eye toward their ramifications among political elites and their effects on the long-run reputation of labor. Unsuccessful interventions in nominating processes will undermine union clout for many years; conversely, persevering 
in one's political commitments, even when a favored candidate seems to be sliding, is one way of making labor's endorsement even more valuable. When labor stuck by $\mathrm{Al}$ Gore through thick and thin in 2000, it made its endorsement worth more in 2004. Future candidates for the Democratic nomination no doubt watched in 2000 as labor dispatched Bradley and helped deliver key battleground states to Gore in the general election. One can expect that these candidates will come knocking on labor's door well before the start of the 2004 nominating process.

Third, while it has often been noted that the decentralization of the U.S. labor movement has weakened its ability to bargain with both politicians and employers, my analysis shows that there may also be some benefits from decentralization. American unionism is structured so that national unions, and even locals within them, frequently pursue very different political strategies. While this dispersion of decision-making capability may undermine the bargaining clout of top union leaders and the federation president, it also means that labor can sometimes get the best of both worlds. In 2000 , for example, the early federation endorsement helped labor to score points with Al Gore, while the delaying tactics of other unions kept some pressure on Gore even after he had won the party nomination. In other cases, the support of some unions for Republican candidates may ensure that labor has access to politicians from this party even as the vast majority of unions endorse Democrats. Potentially, this plural agency allows a kind of "good cop/bad cop" routine in which labor as a whole may gain access and influence that it would miss if it were unambiguously a unitary actor.

Lastly, the analysis suggests that categorizing union strategies as either "dependent" or "independent" - with involvement in the Democratic party invariably viewed as the former and organization of a labor party as the only example of the latter - may obscure more than it reveals. The classification herein suggests that aggressive and skillful bargaining within a two-party system can actually open up avenues of relatively independent political action. Is this not what the Christian Coalition and others have done within the Republican party? Of course, securing promises during an election and ensuring that politicians act on those promises are two different things. And, even if an officeholder does decide to follow through by pushing labor issues, there is no guarantee that he or she will be able to secure the support of others (even presidential support, for example, does not guarantee the acquiescence of Congress). The severe decline in union density, public skepticism towards unions as institutions, the decreased popularity of liberal economic proposals, and the revitalization of many of labor's opponents - all these clearly stand in the way of any maximization of labor influence. Still, a key point remains: American unions have had many problems in electoral politics - a lack of bargaining options, per se, is not among them. 


\section{REFERENCES}

Aronowitz, Stanley. From the Ashes of the Old: American Labor and America's Future. Boston: Houghton Mifflin, 1998.

Berke, Richard L. "Odd Man Out of Race, Nader Rocks Gore's Boat." New York Times, June 23, 2000.

Bok, Derek and John Dunlop. Labor and the American Community. New York: Simon and Schuster, 1970.

Dark III, Taylor E. "Labor and the Democratic Party: A Report on the 1998 Elections." Journal of Labor Research 21 (Fall 2000): 627-40.

The Unions and the Democrats: An Enduring Alliance, Cornell Paperbacks Edition. Ithaca, N.Y.: Cornell University Press, 2001.

Davis, Mike. Prisoners of the American Dream. London: Verso, 1986.

Drew, Elizabeth. Portrait of an Election: The 1980 Presidential Campaign. New York: Simon and Schuster, 1981.

Engel, Steven T. and David J. Jackson. "Wielding the Stick Instead of the Carrot: Labor PAC Punishment of Pro-NAFTA Democrats." Political Research Quarterly 51 (September 1998): 813-28.

Gall, Gilbert. The Politics of Right-to-Work: The Labor Federation As a Special Interest, 1943-1979. New York: Greenwood Press, 1988.

Green, James R. The World of the Worker: Labor in Twentieth Century America. New York: Hill and Wang, 1980.

Greenhouse, Steven. "In a Switch, Unions Begin Recognizing Republican Allies." New York Times, October 25, 1998.

“G.O.P. Protests Bush Ban on Labor Pacts." New York Times, March 13, 2001.

Greenstone, J. David. Labor in American Politics, 2nd ed. Chicago: University of Chicago Press, 1977.

Meyerson, Harold. "Primary Concerns: Race, Class, and Gumption in the March Local Elections." LA Weekly, January 14-20, 2000.

Moody, Kim. An Injury to All: The Decline of American Unionism. New York: Verso Press, 1988.

Rosenthal, Steve. Personal interview with Steve Rosenthal, Political Director, AFL-CIO, Sept. 1, 2000.

Shoch, James. "Contesting Globalization: Organized Labor, NAFTA, and the 1997 and 1998 Fast-Track Fights." Politics and Society 28 (March 2000): 119-50.

United Mine Workers. "United Mine Workers of America Endorses AI Gore." Press Release, September 20,2000 .

Wilson, Graham. Unions in American National Politics. London: Macmillan, 1977. 


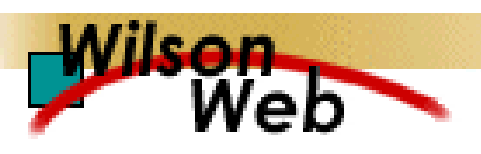

\section{COPYRIGHT INFORMATION}

TITLE: To Reward and Punish: A Classification of Union Political Strategies

SOURCE: J Labor Res 24 no3 Summ 2003

WN: 0319602296010

The magazine publisher is the copyright holder of this article and it is reproduced with permission. Further reproduction of this article in violation of the copyright is prohibited. To contact the publisher: http://www.gmu.edu/

Copyright 1982-2003 The H.W. Wilson Company. All rights reserved. 